\title{
An Emerging Framework for the EdD Activist
}

\author{
Yasha J. Becton \\ University of South Carolina \\ yyjones@mailbox.sc.edu
}

\author{
Elizabeth Currin \\ University of South Carolina \\ ecurrin@mailbox.sc.edu \\ Rhonda Jeffries \\ University of South Carolina \\ rjeffries@sc.edu \\ Suha Tamim \\ University of South Carolina \\ tamims@mailbox.sc.edu
}

\begin{abstract}
Increasingly, Ed.D. programs are challenged to produce graduates with the skills and expertise needed to create and foster change in the various educational environments in which they serve. Promoting, and more importantly, preparing the Ed.D. Activist is a theme that was addressed during the October 2019 convening of the Carnegie Project on the Education Doctorate (CPED) hosted by the University of South Carolina. As part of the opening convening, the $U$ of $S C$ faculty assisted with surveying the more than 65 CPED-informed programs in an effort to construct a potential framework to guide both new and existing programs within the consortium. The resulting framework highlights two potential profiles for the Ed.D. Activist, 12 considerations that programs should examine, four primary outcomes, and five quality indicators. The framework is representative of the data collected from more than 200 participants and provides a broad, but foundational framework for engaging more deeply in the work of promoting activism amongst Ed.D. graduates.
\end{abstract}

KEYWORDS: activism, graduate students, social justice

The authors of this article are faculty members of an online Ed.D. program in Curriculum Studies at an R-1 state university in the Southeast United States. Aligned with the Carnegie Project on the Education Doctorate's (CPED) Program Design Principles, our program's website advertises that the Ed.D. "is designed to provide educators with an in-depth knowledge and understanding of social justice in diverse communities and how to... address problems of practice in various academic settings" ("Doctor of Education Curriculum Studies: What will I study?", n.d.). While activism has not been an explicit goal of our program, we are interested in expanding our social justice framework to include a more deliberate and robust focus on activism. This directly relates to our current pursuit to develop a framework for the Ed.D. Activist.

Our $100 \%$ online program primarily attracts K-12 educators, with a smaller subset of higher education faculty, as well as medical and military personnel. Students come from across the country and abroad, readily identifying a host of problems confronting the schools in their respective locales. In South Carolina, for example, at least 10,000 teachers risked punitive actions from their school districts to attend a rally at the state Capitol to demand action on a wide array of problems they confront daily (Schechter, 2019). According to these teachers' Facebook page, approximately 30,000 educators and supporters participate in an online forum to express their frustrations over myriad injustices levied at educators and their students. Meanwhile, over 40 Ed.D. candidates at our College of Education successfully defend their dissertations each year. They define a problem of practice, apply theory, and review the literature. They implement an intervention, collect and analyze data, and posit the implications. They are duly congratulated at the university's hooding ceremony. They smile and thank their professors for an engaging and eye-opening experience. And then... what? What is expected of them? What do they expect of themselves? In October 2019, the Carnegie Project on the Education Doctorate (CPED) convened to discuss those very questions.

The convening centered on the critical topic of activism, which "is an ambiguous word. It can mean both radical, revolutionary action and nonrevolutionary, community action; action in the service of the nation-state and in opposition to it" (Yang, 2016, p. 1). The theme we developed as host for the convening, "Interaction \& Activism in the Education Doctorate: Creating Lasting Impact," supported our efforts to examine how our students were actively serving as change agents
New articles in this journal are licensed under a Creative Commons Attribution 4.0 United States License.

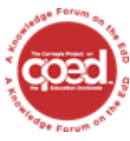

This journal is supported by the Carnegie Project on the Education Doctorate: A Knowledge Forum on the EdD (CPED) cpedinitiative.org 
within the world. In addition to delving deeper into the impact of our Ed.D. program, we also recognized an opportunity, in a much broader context, to stimulate discussion regarding a framework for Ed.D. Activists among CPED-informed degree programs, expanding the existing CPED profiles: The Disrupters, The Change Agents, The Leaders, The Innovators, The Teachers, and The Collaborators.

Developing such a framework could benefit various programs within the CPED consortium. For new programs, the framework might serve as a foundational tool to identify critical elements resident in Ed.D. programs that promote activism and social justice. For more experienced programs, the framework could ensure continuing organizational alignment as it relates to coursework, research practices, and extended learning opportunities. Additionally, a framework with input from more than 100 CPED-affiliated colleges and universities could serve as a comprehensive blueprint for program evaluation and program development. To this end, the University of South Carolina presentation at the convening, "The Emerging Framework of the Ed.D. Activist," focused keenly on defining the construct of an Ed.D. Activist; exploring the coursework, research, and extended learning opportunities conducive to activism; and identifying methods for monitoring program success and outcomes. The purpose of this article is to continue that conversation.

\section{REVIEW OF LITERATURE}

As we give further consideration to the creation of a framework, our review of literature explores several critical components. We first examine the history of the education doctorate as well as its ongoing transformation. Juxtaposed with this history is a discussion of teacher activism with attention to implications for teacher educators. Lastly, we explore social justice and how it directly or indirectly relates to activism among scholarly practitioners. Building on the history of the education doctorate, as well as the longstanding phenomenon of teacher activism, Ed.D. Activism must inherently embody social justice aims.

\section{History of the Education Doctorate}

Doctoral programs emerged in the U.S. in the last half of the nineteenth century. They aimed at transmitting and reproducing knowledge within the traditional disciplines of medicine, law, philosophy, and theology. Eventually, doctoral studies shifted focus toward critical thinking, creativity, and research. Simultaneously, industrial advancements, cultural diversity, and societal changes raised the interest in professional education to meet market needs. The education doctorate expanded access to research-based graduate study and offered new contexts for inquiry around professional practice (Archbald, 2011; Taysum, 2006). No longer catering to early-career, young adult learners only, professional doctorates opened the way for professional part-time students (Archbald, 2011). On the other hand, changes in American society led to increased high school enrollments, reinforcing the need for college educated teachers and giving rise to the education doctorate, the Ed.D. (Archbald, 2011).

Ed.D. students are driven by career/professional development or a love for learning (Hawkes, 2016), and the Ed.D. enables educators to address problems of practice through "research-based and research-driven" principles (Taysum, 2006, p. 330), using their expertise and linking theory to practice (Hawkes, 2016; Taysum,
2006; Tupling \& Outhwaite, 2017). We view the ability of scholarly practitioners to effectively address problems of practice as directly related to the "work" of activism.

However, the growing popularity and the proliferation of Ed.D. programs (Archbald, 2011) come with criticism, bias, and vagueness in differentiation from Ph.D. programs. Shulman et al. (2006) argued that problems in Ed.D. programs are "chronic and crippling" (p. 25). Perceived lack of rigor, compacted formats to meet the needs of working students, absence of community of practice, lack of balance between research and practice, and program structure that mimics the Ph.D. with requirement subtractions confuse the purpose of the Ed.D. and expose it to shortcomings.

In an effort to reclaim the education doctorate, as coined by Shulman et al. (2006), The Carnegie Project on the Education Doctorate (CPED) embarked on redesigning doctoral preparation to meet professional practitioners' needs, naming the capstone project a Dissertation in Practice (DiP). Differentiating it from the traditional five-chapter dissertation, CPED proposes a process of fusing professional practice to academic theory by exploring work-based problems that continue beyond graduation through individual inquiry, collaborative inquiry, or a hybrid approach (Storey \& Maughan, 2014).

Understandably, transformative changes such as those recommended by CPED are challenging to program structures (Reigeluth, 2019). Kennedy, Altman, and Pizano (2018) recommended a repetitious review process to align program policies and principles. Peterson (2017) suggested a tight timeline with a clear mission, identification of future roles for doctoral students, and the use of CPED principles for guidance. Ezzani and Paufler (2018) advised allocating time for faculty collaboration and engagement in the change process. As institutions continue to strive to improve Ed.D. programs (e.g. Buss, 2018; Creighton, 2008; Mertler \& Henriksen, 2018; Normore \& Issa Lahera, 2019; Peterson, 2017), scholarly practice will ultimately permeate the teaching profession. Such permeation is necessary to raise the profile of educators among the general public and, more importantly, among the policymakers who influence the working conditions that give rise to teachers' problems of practice-as well as to their activism.

\section{The History of Activism in Education}

Teacher activism has a long history and a vibrant present, encompassing resistance to unjust IQ tests in the early 20th century (Stoskopf, 1999), grassroots efforts that gave rise to Head Start in the 1960s (Hale, 2012), and far-reaching accountability-era protests (Brown \& Stern, 2018). As teachers continue to engage in activism within and beyond the classroom (Dunn, 2018; Oyler, 2017; Picower, 2012), teacher educators have increasingly expressed a responsibility for their programs to foster teacher activists (Montaño, et al., 2002; Riley \& Solic, 2017).

Activism requires "linking citizens together" (Stout, 2010, p. 13), yet the connections afforded by 21 st-century technologies have also produced so-called slacktivism (Neumayer \& Svensson, 2016). As teacher educators in an online program, we take this concern seriously, turning to Cabrera, Matias, and Montoya's (2017) call for more forward-thinking scholarship on activism that defines what activism is and can be rather than dwelling on what activists have done. Their emphasis on activism rather than activists privileges concrete behavior over variable identity. Similarly, Kluttz and Walter (2018) defined activists as "all persons participating and learning 
within a social movement" (p. 94), which necessitates specifying which movement.

Given how Ed.D. program participants inhabit dual roles as practitioners and students, establishing a clear and cross-cutting definition of activism is paramount. Likewise, we must heed the risks facing "scholar-activists in a neoliberal environment," striving to model scholar-activism for our students (Dunn, 2016, p. 22). Cochran-Smith (2010), who envisioned teachers as "advocates and activists" (p. 457), insisted they cannot engage in such work alone. Thus, the Ed.D. Activism construct must be precisely defined, socioculturally situated, and intentionally scaffolded. In our view, social justice must comprise the core of that construct.

\section{Social Justice and its Relationship to Activism}

Ed.D. Activists must understand the complexity of human rights education and heed the continuous call to calculate and calibrate transformative spaces where ideological explorations about constitutional rights occur. We expect scholarly practitioners to ultimately advance the rights and privileges of women, children, people of color, immigrants, and members of the LGBTQA community (Cianciarulo, 2015; Giroux, 2015; Spreen et al., 2018). This enduring fight for democratic education continues to emerge across the literature as demands for establishing, institutionalizing, and fully practicing justice and equity in schools in the United States are championed. Moreover, effective activist leadership guiding this fight might be realized through a greater reliance on and inclusion of the views, practices, and accomplishments of members of these marginalized groups via cooperative participation (Kezar, Acuña Avilez, Drivalas, \& Wheaton, 2017; King, 2015; Ryan \& Higginbottom, 2017).

We need Ed.D. activists as educational leaders to push public thinking beyond binary exchanges of right versus wrong, female versus male, other versus white, rich versus poor, other versus cis, along with a plethora of oppositional identities that indicate and reify political power. Educational institutions are prime spaces to broaden the narrative about democracy, social justice, and power; however, the primary challenges of changing educational institutions regarding human inequity remain at the forefront of classrooms with instructional leaders (Brooks, Normore, \& Wilkinson, 2017; Jaquette, 2017; Theoharis, 2015). This dilemma is entrenched within the socioeconomic agendas driving the multiple policies that work against a socially just society. Indeed, developing educational activists is especially timely with "many marginally democratic countries hav[ing] become increasingly authoritarian and authoritarian, xenophobic populist movements hav[ing] grown strong enough to threaten democracy's long-term health in several rich, established democracies including ... the United States" (Inglehart, 2018, p. 20). Acknowledging that our present path is diametrically opposed to democratic ideals, educators should rightfully be at the center of activist efforts, which is critical needs work in our current political times.

\section{POSITIONALITY}

The University of South Carolina's Ed.D. Curriculum Studies program was redesigned in 2002 to focus on diversity and again in 2014 to embody a $100 \%$ online format. The program emphasizes concerns for equity, social justice, self-knowledge, cultural issues, and human growth and development through a balanced approach consisting of both theory and practice. Within the program, students gain an in-depth understanding of theory, history, concepts, techniques, strategies, and issues of diversity in $\mathrm{K}-12$ schools, as well as other social institutions and community settings. The degree program is uniquely designed to facilitate self-reflection that in turn promotes engagement in social justice education.

As noted in the introduction, we served as the host institution for the CPED 2019 October convening. At this time, our program consisted of 12 full-time faculty members serving approximately 220 students. We took the opportunity to share our tentative ideas about the emerging framework for the Ed.D. Activist while also eliciting the perspectives of our CPED peers, including what specific programmatic frameworks and assessments were in place to ensure the desired outcome. After investigating the profiles provided on the CPED website-The Disrupters, The Change Agents, The Leaders, The Innovators, The Teachers, and The Collaborators, we saw a need to explicitly identify and articulate the tenets of what we termed the Ed.D. Activist.

\section{THEORETICAL FRAMEWORK}

Examinations of inequity, marginalization, and dissonance in educational settings are critical to the work of the Ed.D. Activist. Ed.D. Activists are then positioned to drive the direction of educational governance as they recognize the increasing importance of inclusivity and acknowledge the power they possess to impact equity through policy (Dulio, O'Brien, \& Klemanski, 2008; Marginson, 2016).

Doctoral programs focused on activism are able to influence future leaders emerging from the ranks of Ed.D. educated instructional leaders. These leaders will ideally possess a working knowledge of structuration theory (Giddens, 1984) and apply it toward inclusive goals in instructional settings and through professional development opportunities (Burridge, Carpenter, Cherednichenko, \& Kruger, 2010). Giddens (1979) described the concept of human action with the overt intent to change power dynamics in education and other political spaces as agency, which is elsewhere illustrated as "identities in motion" (Buchanan, 2015, p. 714). This concept of agency can be seen as complementary to the notion of an activist in that agents challenge established ways of thinking and behaving or what we think of as structure. The disruption of structure or the space for effective activism called agency is a temporal state enabling transformation to emerge. Tural (2017) noted the capacity of structuration theory to support community education agents to respond effectively to the demands of a changing and highly diverse human landscape.

Ed.D. Activists might sustain their work through the use of structuration theory, which further recommends employing a perception that established structure is transient and evolutionary. As such, structures are inevitably replaceable as new intellectual knowledge, practical experience, and personal needs demand change. The cycle of agency and structure is a roadmap to action and meaning construction that continually guides our search for a more socially just experience (Jeffries, 2019). As doctoral education continues to address issues of diversity, equity, and inclusivity, this theoretical framework offers a roadmap to successfully establish fluid and flexible policies that support continuous explorations of efficacious commitment to social justice (Berila, 2015; WinkleWagner \& Locks, 2013). Frameworks of this nature demand that we surpass simplistic ways of thinking about equity in education and 
strive for including diverse perspectives at the multiple decisionmaking spaces where revolutionary change can expand educational opportunities.

\section{METHODOLOGICAL FRAMEWORK}

Without formal processes for documenting the outcomes associated with activism among our Ed.D. graduates, we recognized the need to develop a framework that could 1) describe the characteristics of an Ed.D. Activist, 2) suggest strategies that promote Ed.D. Activism, and 3) measure the impact of Ed.D. Activism among our students and graduates in their local communities. Given the emphasis on activism among the members of the CPED community (Becton et al., 2019), we felt the inclusion of diverse perspectives from the CPED community would lead to the development of a more broadly useful framework for Ed.D. Activism.

Because we aimed to generate a new understanding of Ed.D. Activism exclusively from the data collected in this study, we selected grounded theory as our methodological approach (Strauss \& Glaser, 1967). Grounded theory, a qualitative research methodology with high regard in the education research community (Thomas \& James, 2006), is a systematic, flexible, empirical, and creative process of knowledge generation from which the results can be shared, discussed, and in turn, direct future research efforts (Coe et al., 2017; Morse et al., 2009). We purposefully sampled a homogenous group (Patton, 2007) of CPED members who attended an interactive, general session presented at a recent convening (CPED, 2019).

Facilitators used the following prompts for breakout sessions, which serve as the research questions for this article:

1. Profile of the Activist: How would you describe The Activist? What attributes, characteristics, and actions reflect The Activist?

2. Ed.D. Program Strategies to Facilitate/Support The Activist (or Activism): Discuss current program strategies including, but not limited to, coursework, culminating work/product (dissertation, project), mentoring, conference attendance, publication opportunities, etc.

3. Measuring Progress Toward Ed.D. Development/Support of The Activist: Discuss potential outcomes and quality indicators to understand how components of the Ed.D. program and the overall Ed.D. program are developing and supporting the Ed.D. Activist.

During the breakout sessions, 200+ participants sat at large round tables in groups of 4-8 people. A color-coded version of each prompt was provided, and groups were asked to identify one person to serve as the recorder to reflect the general discussion and ideas generated from the group for each prompt.

The questionnaires were collected at the end of the presentation, scanned, digitally transcribed, and organized into three subsets, each aligned with one aspect of our emerging framework. Two researchers concurrently but independently reviewed each data subset using a constant comparative method to identify open, axial, and core codes (Strauss \& Corbin, 1990). For each subset, open codes were identified by each researcher individually. In accordance with constant comparative methods, the identification of new codes in subsequent pieces of data led to the reanalysis of previously reviewed pieces of data to ensure new codes were not missed in previously analyzed data (Strauss \& Corbin, 1990). This process continued until the analysis of new pieces of data yielded no new codes, thus achieving saturation (Guest, Bunce, \& Johnson, 2006). Once individual coding was completed, the researchers discussed their codes to determine consensus. This process was then repeated for the determination of axial codes and themes in the data, as well as for the identification of core codes as needed (Strauss \& Corbin, 1990).

\section{DISCUSSION AND FINDINGS}

The findings from the grounded theory coding approach are presented for each prompt.

\section{Profile of The Activist}

Researchers identified open codes related to attributes, actions, and characteristics of The Activist. Codes were developed through a constant comparison approach based on the written responses to Prompt 1) and its guiding questions: "How would you describe The Activist? What attributes, characteristics, and actions reflect The Activist?" Sentences, phrases, and words from the reporting templates were combined in open coding to ensure representativeness but avoid duplication. Table 1 includes the open codes and the axial codes that were developed based on the grouping of open codes. 


\begin{tabular}{|l|l|}
\hline Open Codes & Axial Codes \\
\hline $\begin{array}{l}\text { Inspirer, Empathetic, Invested/Committed } \\
\text { Inclusive, Negotiation Skills } \\
\text { Action Oriented, Open-Minded }\end{array}$ & Coalition Builder \\
\hline $\begin{array}{l}\text { Courage, Open to Risk } \\
\text { Strong Voices, Disrupter }\end{array}$ & Vocal Risk-taker \\
\hline $\begin{array}{l}\text { Inquisitive, Inquiry Mindset } \\
\text { Leader, Problem Identifier } \\
\text { Change Oriented, Reflective, Integrity }\end{array}$ & Visionary Leader \\
\hline $\begin{array}{l}\text { Critical, Social Justice, Awareness of Inequity, } \\
\text { Dissatisfaction with Current Situations, Integrity }\end{array}$ & Social Justice Champion \\
\hline
\end{tabular}

Table 1. Profile of the Activist

Rather than a clearly-defined profile of an Ed.D. Activist, what emerged from the responses of more than 65 CPED-informed colleges and universities were four themes, represented by the axial codes in Table 1. Echoing Buchanan's (2015) definition of agency as "identities in motion" (p. 714), these themes transform the "attributes, characteristics, and actions" supplied by our participants into actionoriented nouns. While an Ed.D. Activist could conceivably exhibit aspects of all four identities, it is also possible to envision four unique Ed.D. Activists, each representative of one of the axial codes. It bears repeating that this is an emerging framework, and we do not wish to suggest a one-size-fits-all approach. Below, we elaborate on each theme.

A Coalition Builder, based on participant feedback, inspires and focuses on bringing people together for a common cause. This requires negotiation skills and the wherewithal to foster collaboration. Collaboration results in the forging of something new and stronger than what a single individual or agency can achieve in isolation (Kinsella-Meier \& Gala, 2016). The Coalition Builder has the ability to galvanize forces and build consensus within an organization.

Another theme in the data suggested an activist is a Vocal Risktaker, one who gives voice to critical issues and topics and also possesses the courage necessary for activism. Indeed, activism often leads to negative consequences experienced by those who stand up to voice concerns, such that "teachers fear the reactions of their principals, principals fear the reactions of their superintendents and communities, and superintendents fear the responses of the school boards and communities" (Hoffman, 2009, p. 391). Vocal Risk-takers juggle competing political, social, and economic forces all while becoming "more confident in resisting the dominant discourses in order to advocate for those typically marginalised and powerless in Society" (Hoffman, 2009, p. 392).

An additional theme evident in the data suggested The Ed.D. Activist is a Visionary Leader, always thinking intuitively about how to cultivate a more progressive future. Visionary Leaders engage in critical reflection to solve authentic problems, exhibiting the kind of vision that is a necessary precursor for organizational change. As Mack (2015) argues, vision "serves as a bridge between the present and the future, and it is intentionally aspirational" (p. 10). Through inquiry, Ed.D. Activists exhibit this sort of forward-thinking.

The fourth theme in the data characterized The Ed.D. Activist as a Social Justice Champion, one who can quickly and readily identify the inequities and injustices that may go unnoticed in a particular work environment. Continually focused on equity and fairness, Social Justice Champions truly desire to make a difference and recognize how "operationalizations of social justice are constantly evolving and shifting in the same proportion as cultural groups act on their emerging sense of agency" (Rodriguez \& Morrison, 2019, p. 262). 


\begin{tabular}{|c|c|c|}
\hline & OPEN CODES & AXIAL CODES \\
\hline \multirow[t]{2}{*}{$\begin{array}{l}\text { Coursework/Focus in } \\
\text { Coursework }\end{array}$} & $\begin{array}{l}\text { Social Justice, Race, Reality, Poverty, Activism for } \\
\text { Professionals, Leadership, Multicultural Education }\end{array}$ & $\begin{array}{l}\text { Coursework Specific to Social } \\
\text { Justice, Multicultural Education } \\
\text { and/or Leadership }\end{array}$ \\
\hline & $\begin{array}{l}\text { Community Leadership, School Community Policy } \\
\text { (Education, Health) }\end{array}$ & $\begin{array}{l}\text { Coursework Related to or Involving } \\
\text { the Community }\end{array}$ \\
\hline \multirow[t]{2}{*}{$\begin{array}{l}\text { Coursework/Focus in } \\
\text { Coursework (continued) }\end{array}$} & $\begin{array}{l}\text { Critical Literature Review, Credibility of Evidence, Problem } \\
\text { of Practice, Action Research, Practitioner Inquiry, } \\
\text { Ethnography, Scholarly Narrative, Critical Participatory } \\
\text { Action Research }\end{array}$ & $\begin{array}{l}\text { Coursework Related to Research } \\
\text { and/or the Dissertation in Practice }\end{array}$ \\
\hline & $\begin{array}{l}\text { Course Sequencing } \\
\text { Evidence-based Program Design, Needs Assessment }\end{array}$ & Overall Course Design \\
\hline \multirow[t]{2}{*}{$\begin{array}{l}\text { Dissertation or Final } \\
\text { Project }\end{array}$} & Require Focus in Social Justice/Community & $\begin{array}{l}\text { Social Justice Related Focus } \\
\text { for the Dissertation }\end{array}$ \\
\hline & $\begin{array}{l}\text { Student Professional/Personal } \\
\text { Goals, Action Plan Required }\end{array}$ & $\begin{array}{l}\text { Inclusion of Student's Career and } \\
\text { Professional Goals }\end{array}$ \\
\hline \multirow[t]{2}{*}{$\begin{array}{l}\text { Dissertation or Final } \\
\text { Project (Continued) }\end{array}$} & $\begin{array}{l}\text { Scholarly Narrative, Participatory Approach, Action } \\
\text { Research, Include Indigenous Sources }\end{array}$ & $\begin{array}{l}\text { Considerations Relative to the } \\
\text { Research and Writing of } \\
\text { Dissertation }\end{array}$ \\
\hline & $\begin{array}{l}\text { Promote Innovation, Symposia to Present, } \\
\text { Approach/Findings }\end{array}$ & $\begin{array}{l}\text { Considerations for } \\
\text { Dissertation Defense or } \\
\text { Final Presentation }\end{array}$ \\
\hline OTHER & $\begin{array}{l}\text { Institutional Inequities } \\
\text { Ed.D. Admission Inequities }\end{array}$ & $\begin{array}{l}\text { Addressing Inequity in } \\
\text { Institutions, Policies, } \\
\text { Methodological } \\
\text { Approaches, Ed.D. } \\
\text { Programs (faculty and } \\
\text { students) }\end{array}$ \\
\hline \multirow[t]{3}{*}{ OTHER (CONTINUED) } & $\begin{array}{l}\text { Dissertation Requirements (social justice focus) } \\
\text { Alignment/Repetition in Course Sequence }\end{array}$ & $\begin{array}{l}\text { Defined and Supported Dissertation } \\
\text { Process }\end{array}$ \\
\hline & $\begin{array}{l}\text { Mentorship } \\
\text { Leadership Opportunities } \\
\text { Diverse Staff and Faculty }\end{array}$ & $\begin{array}{l}\text { Mentoring/Supporting Students and } \\
\text { Graduates }\end{array}$ \\
\hline & $\begin{array}{l}\text { Writing Articles/Co- } \\
\text { Authorship, Methodological } \\
\text { Philosophies, Community } \\
\text { Study/Study Abroad }\end{array}$ & $\begin{array}{l}\text { Scholarly and Practitioner Inquiry } \\
\text { Activities }\end{array}$ \\
\hline
\end{tabular}

Table 2. Strategies to Facilitate/Support The Activist

After the discussion related to the Profile of The Activist, facilitators asked small groups to discuss how Ed.D. programs facilitate or support activism, using Prompt 2 and its guiding statement: "Discuss current program strategies including, but not limited to, coursework, culminating work/product (dissertation, project), mentoring, conference attendance, publication 
opportunities, etc." The same process was used to analyze the written responses related to Prompt 2, outlined in Table 2.

One of the primary findings from this study is that through the feedback of the participants of the October CPED convening, we are able to now clearly identify several basic and fundamental strategies that CPED-informed Ed.D. programs could employ when cultivating an activism focus. Beyond providing students with a profile of an Activist, colleges and universities must commit to having certain structures and supports in place. The institutions participating in this research identified 12 key areas of consideration noted in Table 3.

Although several of the 12 identified considerations would not be considered unique to Ed.D. programs, consideration number 2 is an exception. Participants cited a need for potential graduates to have or experience a level of engagement within their community. While the other 11 considerations reflect an academic focus, number 2 speaks more to the Ed.D. graduates' need to connect with people, echoing Noddings's (2004) recommendation to "take on the other's reality as possibility and begin to feel its reality," to the point of being "impelled to act as though on [one's] own behalf, but in reality on behalf of the other" (p. 46).

12 Considerations to Support the Ed.D. Activist (not listed in order of priority)

1. Coursework Specific to Social Justice, Multicultural Education and/or Leadership

2. Coursework Related to or Involving the Community

3. Coursework Related to Research and/or Dissertation in Practice

4. Overall Course Design

5. Social Justice Related Focus for the Dissertation

6. Inclusion of Student's Career and Professional Goals

7. Considerations Relative to the Research and Writing of Dissertation

8. Considerations for Dissertation Defense or Final Presentation

9. Addressing Inequity in Institutions, Policies, Methodological

Approaches, Ed.D. Programs (faculty and students)

10. Defined and Supported Dissertation Process

11. Mentoring/Supporting Students and Graduates

12. Scholarly and Practitioner Inquiry Activities

Table 3. 12 Considerations to Support the Ed.D. Activist
Along with community connections, the social justice commitments of Ed.D. Activists can manifest in civic engagement (Krings et al., 2015). Additionally, it has positive effects on academic, personal, social, and citizenship outcomes (Conway et al., 2009). Thinking critically about social issues through service learning sparks students' motivation to act toward social change (Kajner, et al., 2013). Moreover, reflecting on complex problems, goals, and strategies inspires them to move from problem identification to problem solving in their activism (Jacoby, 2017). Particularly for teachers, community involvement empowers them to make decisions, lead, learn about community needs, and collaborate toward finding solutions (Jarrett \& Stenhouse, 2011). Therefore, community involvement (Consideration 2) coupled with coursework specific to social justice, multicultural education, and/or leadership (Consideration 1) combine to provide a more distinct and unique picture of an Ed.D. Activist.

\section{Measuring Progress Toward Ed.D. Development/Support of the Activist}

For the final breakout discussion, facilitators moved to Prompt 3 and its guiding statement: "Discuss potential outcomes and quality indicators to understand how components of the Ed.D. program and the overall Ed.D. program are developing and supporting the Ed.D. Activist" is detailed in Table 4. 


\begin{tabular}{|c|c|c|}
\hline & OPEN CODES & AXIAL CODES \\
\hline \multirow[t]{4}{*}{ OUTCOMES } & $\begin{array}{l}\text { Dissertation must focus on Problem of Practice } \\
\text { Dissertation ideas developed by end up 1st yr with } \\
\text { committee members identified } \\
\text { Develop a dissertation mentoring } 1,2,3 \text { step process- to } \\
\text { complete dissertation. } \\
\text { As a content analysis of dissertations, to see if they are } \\
\text { focused on change, social justice. }\end{array}$ & $\begin{array}{l}\text { Progress related to } \\
\text { Dissertation }\end{array}$ \\
\hline & $\begin{array}{l}\text { Organizational Change } \\
\text { Socially Just Policies } \\
\text { Inclusivity } \\
\text { Improvement } \\
\text { Continuous Quality Improvement Cycles } \\
\text { Interventions }\end{array}$ & $\begin{array}{l}\text { Graduates Promoting Change } \\
\text { within Organizations }\end{array}$ \\
\hline & $\begin{array}{l}\text { Being able to articulate concerning Social Justice issues } \\
\text { Growth over time }\end{array}$ & $\begin{array}{l}\text { Students Exemplifying Certain } \\
\text { Characteristics }\end{array}$ \\
\hline & $\begin{array}{l}\text { Contribute to Public Discourse in Education } \\
\text { Action Orientation } \\
\text { Graduates' Orientation toward Practice } \\
\text { Identify and Address Problems of Practice in their } \\
\text { workplace } \\
\text { Graduates' Roles in Organizations/Community } \\
\text { A postdoctoral network of EdD graduates so they } \\
\text { continue to apply activist principles }\end{array}$ & $\begin{array}{l}\text { Graduates Demonstrate } \\
\text { Leadership after program }\end{array}$ \\
\hline \multirow[t]{3}{*}{$\begin{array}{l}\text { QUALITY } \\
\text { INDICATORS }\end{array}$} & $\begin{array}{l}\text { Publications } \\
\text { Policy Briefs by Students/Alumni } \\
\text { Review of Alumni Work } \\
\text { Presentations } \\
\text { Student's Dispositions } \\
\text { External Dissertation Review }\end{array}$ & $\begin{array}{l}\text { Analysis of Students' } \\
\text { Dissertations, Publications \& } \\
\text { Other Professional Writings }\end{array}$ \\
\hline & $\begin{array}{l}\text { Surveys } \\
\text { Exit Interviews } \\
\text { Artifacts }\end{array}$ & Analysis of Student Feedback \\
\hline & Review of Ed.D. Applications - Equity & $\begin{array}{l}\text { Ensuring Equity within the } \\
\text { Program }\end{array}$ \\
\hline
\end{tabular}

Table 4. Outcomes and Quality Indicators to Measure Progress Toward the Developing Activist 


\section{IMPLICATIONS}

The Profile of an Ed.D. Activist will likely vary from program to program. Among the researchers engaged in this study, a lively debate about whether we have uncovered a single profile or multiple profiles impressed upon us the importance of recognizing our conceptualization may differ significantly from faculty in other programs. If so, the implications of this emerging profile likewise differ. With this in mind, we decided to share both a single-profile model of a multi-faceted Ed.D. Activist and a multi-profile model proposing four distinct kinds of Ed.D. Activists

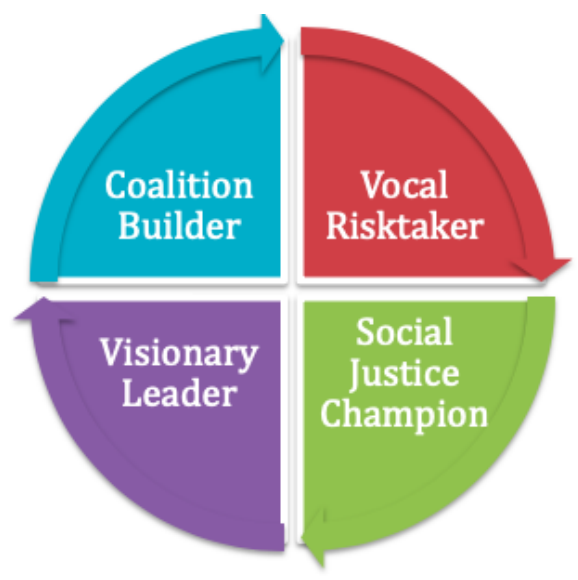

Figure 1. The Single Profile Model

\section{The Single-Profile Model}

Based on the themes uncovered by Prompt 1, this model incorporates all four themes into one, cohesive profile. This tentative model suggests that each graduate of an Ed.D. program may embody all four aspects but to varying degrees. For example, one graduate might see themselves as a skilled coalition builder but a bit reluctant to take large risks. Another graduate might feel a deep sense of commitment to others and thus be motivated to contribute to the work of rectifying issues of social justice yet remain somewhat hesitant to take on a leadership role. In other words, each graduate will demonstrate the four aspects to varying degrees based on their unique abilities. Programs that desire to have graduates embody this comprehensive model of an Ed.D. Activist should think critically and strategically about how their Ed.D. program will provide the necessary foundation for students to emerge with the complete skill set representative of this model.

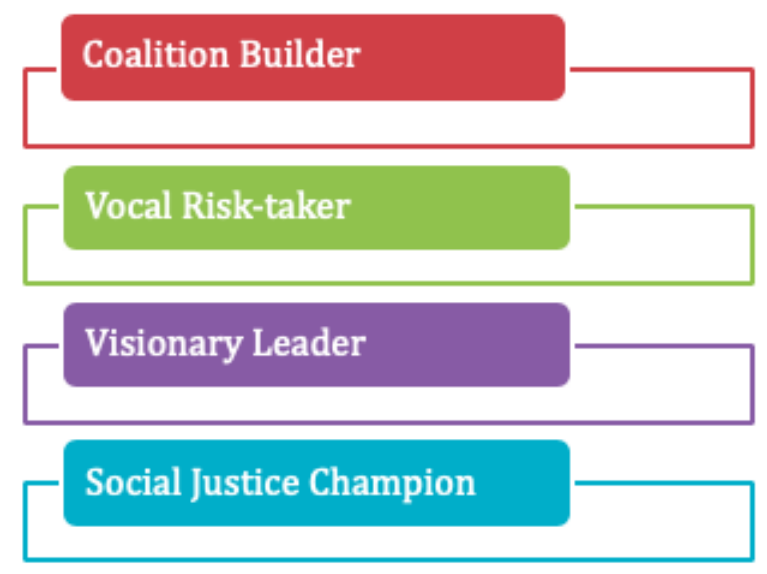

Figure 2. The Multi-Profile Model

\section{The Multi-Profile Model}

Some individuals and programs might prefer the multi-profile model, wherein each individual student is afforded the opportunity to identify each distinct profile as an option or a type of leadership that can be embraced within the work of activism. For example, a more introverted leader may aspire to serve as a Coalition Builder or a Visionary Leader, drawing on their ability to create harmony and productivity within a group. Conversely, this individual may never aspire to serve in the capacity of a Vocal Risk-taker. From a programmatic standpoint, we further recognize that programs can have a more centralized focus. For example, our program focuses more on the development of a Social Justice Champion, although this model could guide us to reevaluate our program and our intended outcomes to determine whether or not we should focus more attention on the other three profiles.

\section{CONCLUSION}

As Ed.D. programs expand and refine their visions and missions around the notion of activism, this framework can and should evolve. The enduring question for programs committed to educational equity and access is whether we focus on developing emerging activists, growing our burgeoning activists, or strengthening our functioning activists. One thing is clear: Ed.D. graduates who influence positive and impactful change will use their activist lenses to rightfully justify our next-generation decisions.

Professional development opportunities with enduring impact, such as Ed.D. programs, increase their imprint on the field through their effectual alignment with the Carnegie Project on the Education Doctorate (CPED). This influential collaborative will continue to provide the space to revise and fine-tune the conceptual knowledge that shapes and defines the Ed.D. Activist, and the concept of structuration theory can aptly guide the progression of these educator identities and this revolutionary model. This early iteration of the Ed.D. Activist model (Figure 3) should be seen as fluid and evolving in response to the needs of our doctoral scholars, and more importantly, the students whom they serve. 


\section{CPED-INFORMED FRAMEWORK FOR THE Ed.D. ACTIVIST}

\section{Single Profile Model}

Each Ed.D. graduate embodies each of the 4 components.

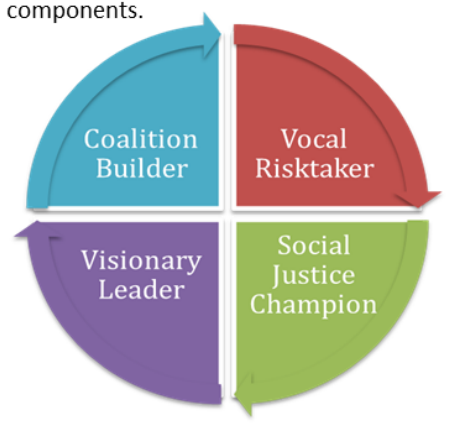

Multi-Profile Model

Each Ed.D. graduate embodies at least one of the 4 com-

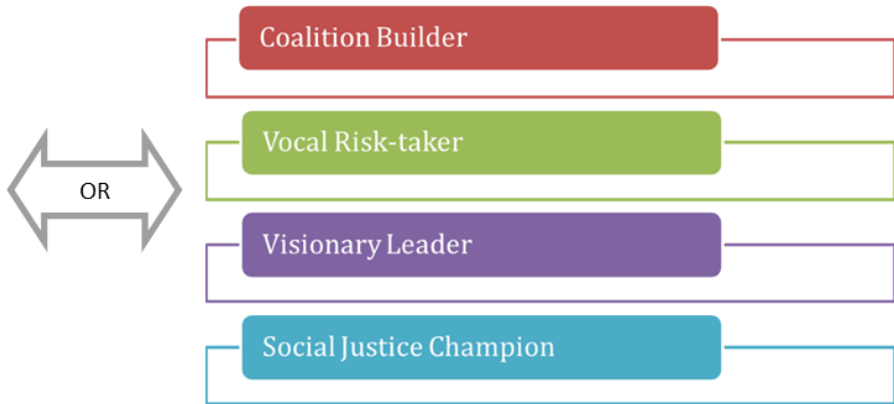

\section{Considerations to Support the Ed.D. Activist}

\begin{tabular}{|c|c|c|c|c|c|}
\hline $\begin{array}{l}\text { Coursework Specific to } \\
\text { Social Justice, Multicul- } \\
\text { tural Education and/or } \\
\text { Leadership }\end{array}$ & $\begin{array}{l}\text { Coursework Related } \\
\text { to or Involving the } \\
\text { Community }\end{array}$ & $\begin{array}{l}\text { Coursework Relat- } \\
\text { ed to Research } \\
\text { and/or the Disser- } \\
\text { tation in Practice }\end{array}$ & $\begin{array}{l}\text { Overall Course } \\
\text { Design }\end{array}$ & $\begin{array}{l}\text { Social Justice } \\
\text { Related Focus } \\
\text { for the Disser- } \\
\text { tation }\end{array}$ & $\begin{array}{l}\text { Inclusion of } \\
\text { Student's Ca- } \\
\text { reer and Pro- } \\
\text { fessional Goals }\end{array}$ \\
\hline $\begin{array}{l}\text { Considerations Relative } \\
\text { to the Research and } \\
\text { Writing of Dissertation }\end{array}$ & $\begin{array}{l}\text { Considerations for } \\
\text { Dissertation Defense } \\
\text { or Final Presentation }\end{array}$ & $\begin{array}{l}\text { Attention to Ineq- } \\
\text { uity in Institutions, } \\
\text { Policies, Methodo- } \\
\text { logical Approaches, } \\
\text { Ed.D. Programs } \\
\text { (faculty and stu- } \\
\text { dents }\end{array}$ & $\begin{array}{l}\text { Defined and Sup- } \\
\text { ported Disserta- } \\
\text { tion Processes }\end{array}$ & $\begin{array}{l}\text { Mentorship } \\
\text { Support for } \\
\text { Students and } \\
\text { Graduates }\end{array}$ & $\begin{array}{l}\text { Scholarly and } \\
\text { Practitioner } \\
\text { Inquiry Activi- } \\
\text { ties }\end{array}$ \\
\hline
\end{tabular}

\section{OUTCOMES}
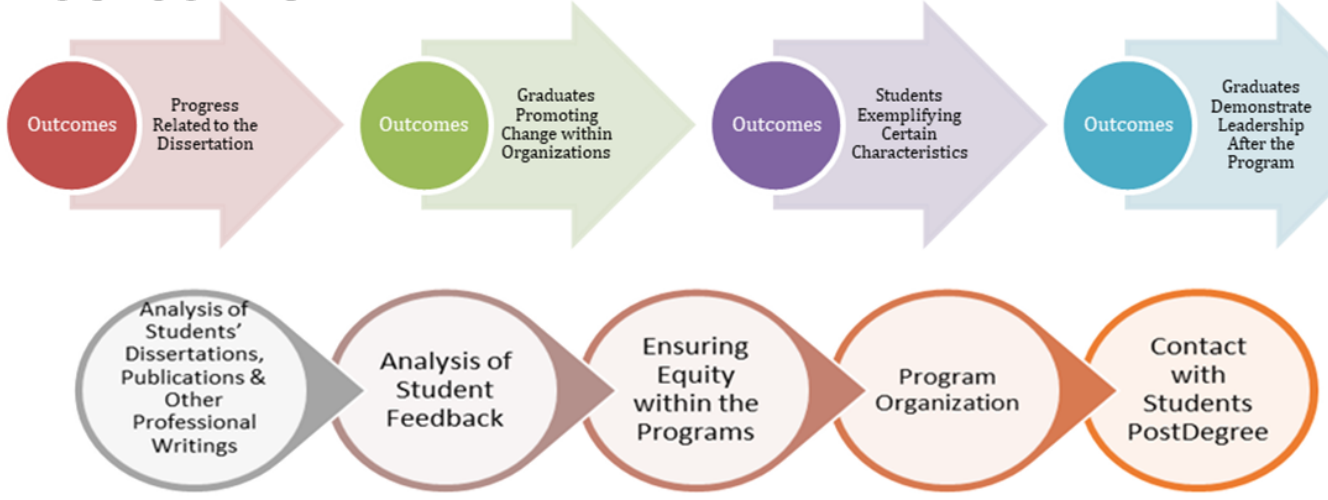

5 Quality Indicators

Figure 3. CPED-Informed Framework for the Ed.D. Activist 


\section{REFERENCES}

Archbald, D. (2011). The emergence of the nontraditional doctorate: A historical overview. New Directions for Adult and Continuing Education, 129(Spring), 7-19. https://doi.org/10.1002/ace

Becton, Y., Bogiages, C., Currin, E., D’Amico, L., Jeffries, R., Lilly, T., \& Tamim, S. (2019, October 22). An emerging framework for the EdD activist [Conference session]. Carnegie Project on the Education Doctorate, Columbia, SC, United States.

Berila, B. (2015). Integrating mindfulness into anti-oppression pedagogy: Social justice in higher education. New York, NY: Routledge.

Brooks, J. S., Normore, A. H., \& Wilkinson, J. (2017). School leadership, social justice and immigration: Examining, exploring and extending two frameworks. International Journal of Educational Management, 31(5), 679-690.

Brown, A. E., \& Stern, M. (2018). Teachers' work as women's work: Reflections on gender, activism, and solidarity in new teacher movements. Feminist Formations, 30(3), 172-197.

Buchanan, R. (2015). Teacher identity and agency in an era of accountability. Teachers and Teaching: theory and practice, 21(6), 700-719.

Burridge, P., Carpenter, C., Cherednichenko, B., \& Kruger, T. (2010). Investigating praxis inquiry within teacher education using Giddens' structuration theory. Journal of Experiential Education, 33(1), 19-37.

Buss, R. R. (2018). How CPED guiding principles and design concepts influenced the development and implementation of an Ed.D. program. Impacting Education: Journal on Transforming Professional Practice, 3(2), 40-47. https://doi.org/10.5195/ie.2018.57

Cabrera, N. L., Matias, C. E., \& Montoya, R. (2017, April 3). Activism or slacktivism? The potential and pitfalls of social media in contemporary student activism. Journal of Diversity in Higher Education, 10(4), 400415.

Cianciarulo, M. S. (2015). Refugees in our midst: Applying international human rights law to the bullying of LGBTQ youth in the United States. Columbia Human Rights Law Review, 47, 55.

Cochran-Smith, M. (2010). Toward a theory of teacher education for social justice. In A. Hargreaves, A. Lieberman, M. Fullan, \& D. Hopkins (Eds.), Second international handbook of educational change (pp. 445-467). Dordrecht, NL: Springer.

Coe, R., Waring, M., Hedges, L., \& Arthur, L. (Eds). (2017). Reinventing grounded theory: Some questions about theory, ground and discovery (2nd ed.). Thousand Oaks, CA: Sage.

Conway, J. M., Amel, E. L., \& Gerwien, D. P. (2009). Teaching and learning in the social context: A meta-analysis of service learning's effects on academic, personal, social, and citizenship outcomes. Teaching of Psychology, 36(4), 233-245. https://doi.org/10.1080/00986280903172969

Creighton, T. (2008). Logic models: Evaluating education doctorates in educational administration. International Journal of Educational Leadership Preparation, 3(1), 1-11.

Doctor of Education - Curriculum Studies: What will I study? (n.d.). Retrieved from https://www.sc.edu/study/colleges_schools/education/index.php.

Dulio, D. A., O’Brien, E. E., \& Klemanski, J. S. (Eds.). (2008). Diversity in contemporary American politics and government. London, UK: Pearson College Division.

Dunn, A. H. (2016). "It's dangerous to be a scholar-activist these days": Becoming a teacher educator amidst the hydra of teacher education. Teacher Education Quarterly, 43(4), 3-29.

Dunn, A. H. (2018). Leaving a profession after it's left you: Teachers' public resignation letters as resistance amidst neoliberalism. Teachers College Record, 120(9), 1-35.

Ezzani, M. D., \& Paufler, N. A. (2018). Doctoral program in educational leadership redesign: Utilizing a multicriteria framework. Impacting Education: Journal on Transforming Professional Practice, 3(2), 11-16. https://doi.org/10.5195/ie.2018.70.

Giddens, A. (1979). Agency, structure. In Central problems in social theory (pp. 49-95). London, UK: Palgrave.

Giddens, A. (1984). The constitution of society: Outline of the theory of structuration. Berkeley, CA: University of California Press.
Giroux, H. A. (2015). Democracy in crisis, the specter of authoritarianism, and the future of higher education. Journal of Critical Scholarship on Higher Education and Student Affairs, 1(1), Article 7. Available at: https://ecommons.luc.edu/jcshesa/vol1/iss $1 / 7$.

Guest, G., Bunce, A., \& Johnson, L. (2006). How many interviews are enough?: An experiment with data saturation and variability. Field Methods, 18(1), 59-82.

Hale, J. (2012). The struggle begins early: Head Start and the Mississippi Freedom Movement. History of Education Quarterly, 52(4), 506-534.

Hawkes, D. (2016). Why do a professional doctorate? Evidence from prospective EdD students. International Journal of Continuing Education and Lifelong Learning, 8(2), 34-47.

Hoffman, L. (2009). Educational leadership and social activism: A call for action. Journal of Educational Leadership and History, 41(4), 391-410.

Inglehart, R. (2018). The age of insecurity: Can democracy save itself. Foreign Affairs, 97(3), 20-28.

Jacoby, B. (2017). The new student activism: Supporting students as agents of social change. Journal of College and Character, 18(1), 1-8. https://doi.org/10.1080/2194587x.2016.1260479

Jaquette, J. S. (2017). Women at the top: Leadership, institutions and the quality of democracy. In V. Montecinos (Ed.), Women presidents and prime ministers in post-transition democracies (pp. 37-58). London, UK: Palgrave Macmillan.

Jarrett, O., \& Stenhouse, V. (2011). Problem solution project: Transforming curriculum and empowering urban students and teachers. Urban Education, 46(6), 1461-1495.

Jeffries, R. (Ed.). (2019). Diversity, equity, and inclusivity in contemporary higher education. Hershey, PA: IGI Global.

Kajner, T., Chovanec, D., Underwood, M., \& Mian, A. (2013). Critical community service learning: Combining critical classroom pedagogy with activist community placements. Michigan Journal of Community Service Learning, 19(2), 36-48.

Kennedy, B. L., Altman, M., \& Pizano, A. (2018). Engaging in the battle of the snails by challenging the traditional dissertation model. Impacting Education: Journal on Transforming Professional Practice, 3(1), 4-12. https://doi.org/10.5195/ie.2018.27

Kezar, A., Acuña Avilez, A., Drivalas, Y., \& Wheaton, M. M. (2017). Building social change oriented leadership capacity among student organizations: Developing students and campuses simultaneously. New Directions for Student Leadership, 155, 45-57.

King, J. E. (2015). A Black woman speaks on leadership. In Dysconscious racism, afrocentric praxis, and education for human freedom: Through the years I keep on toiling (pp. 36-43). New York, NY: Routledge.

Kinsella-Meier, M. A., \& Gala, N. M. (2016). Collaboration: Definitions and explorations of an essential partnership. Odyssey: New Directions in Deaf Education, 17, 4-9.

Kluttz, J., \& Walter, P. (2018). Conceptualizing learning in the climate justice movement. Adult Education Quarterly, 68(2), 91-107.

Krings, A., Austic, E.A., Gutierrez, L. M., \& Dirksen, K.E. (2015). The comparative impacts of social justice educational methods on political participation, civic engagement, and multicultural activism. Equity and Excellence in Education, 48(3), 403-417.

Mack, G. (2015). Visionary leadership: Chartering a course through the storms. Techniques: Connecting Education \& Careers, 90(3), 10-11.

Marginson, S. (2016). The worldwide trend to high participation higher education: Dynamics of social stratification in inclusive systems, Higher Education, 72(4), 413-434, doi 10.1007/s10734-016-0016-x.

Mertler, C. A., \& Henriksen, D. (2018). Creative and innovative solutions to accommodate the growth of a professional practice doctoral program. Impacting Education: Journal on Transforming Professional Practice, 3(1), 36-44. https://doi.org/10.5195/ie.2018.55

Montaño, T., Lopez-Torres, L., DeLissovoy, N., Pacheco, M., \& Stillman, J. (2002). Teachers as activists: Teacher development and alternate sites of learning. Equity \& Excellence in Education, 35(3), 265-275.

Morse, J., Stern, P., Corbin, J., Bowers, B., Charmaz, K. \& Clarke, A. (2009). Developing grounded theory: The second generation. Walnut Creek, CA: Left Coast Press Inc.

Neumayer, C., \& Svensson, J. (2016). Activism and radical politics in the digital age: Towards a typology. Convergence: The International Journal of Research into New Media Technologies, 22(2), 131-146. 
Noddings, N. (2004). Caring, 1981. In W.F. Pinar (Ed.). Contemporary curriculum discourses: Twenty years of JCT (pp. 42-55). New York: NY: Peter Lang. (Original work published 1999)

Normore, A. H., \& Issa Lahera, A. (2019). The evolution of educational leadership preparation programmes. Journal of Educational Administration and History, 51(1), 27-42. https://doi.org/10.1080/00220620.2018.1513914

Oyler, C. J. (2017). Constructive resistance: Activist repertoires for teachers. Language Arts, 95(1), 30-39.

Patton, M.Q. (2007). Sampling, qualitative (purposive). The Blackwell Encyclopedia of Sociology.

Peterson, D. S. (2017). Preparing scholarly practitioners: Redesigning the EdD to reflect CPED principles. Impacting Education: Journal on Transforming Professional Practice, 2(1), 33-40. https://doi.org/10.5195/ie.2017.30

Picower, B. (2012). Teacher activism: Enacting a vision for social justice. Equity \& Excellence in Education, 45(4), 561-574.

Reigeluth, C. M. (2019). Chaos theory and the sciences of complexity: Foundations for transforming educational systems. Learning, Design, and Technology, 1-12. https://doi.org/10.1007/978-3-319-17727-4_95-1

Riley, K., \& Solic, K. (2017). "Change happens beyond the comfort zone": Bringing undergraduate teacher-candidates into activist teacher communities. Journal of Teacher Education, 68(2), 179-192.

Rodriguez, A., \& Morrison, D. (2019). Expanding and enacting transformative meanings of equity, diversity and social justice in science education. Cultural Studies of Science Education, 14(2), 265-281.

Ryan, J., \& Higginbottom, K. (2017). Politics, activism, and leadership for social justice in education. In D. Waite \& I. Bogotch (Eds.), The Wiley International Handbook of Educational Leadership, (pp. 103-124) Hoboken, NJ: Wiley \& Sons.

Schechter, M. (2019, May 6). 10,000 people marched. Where does the SC teacher movement go from here? The State. Retrieved from https://www.thestate.com/news/politics government/article229939669.html

Shulman, L. S., Golde, C. M., Bueschel, A. C., Kristen, J., Shulman, L. S. Golde, C. M., ... Garabedian, K. J. (2006). Reclaiming education's doctorates: A critique and a proposal. Educational Researcher, 35(3), 25-32.

Spreen, C. A., Monaghan, C., \& Hillary, A. (2018). From transforming human rights education to transformative human rights education: Context, critique, and change. In M. Zembylas \& A. Keet (Eds.), Critical human rights, citizenship, and democracy education: Entanglements and regenerations (pp. 209-224). New York, NY: Bloomsbury Publishing.

Stenhouse, V., \& Jarrett, O. (2012). In the service of learning and activism: Service learning, critical pedagogy, and the problem solution project. Teacher Education Quarterly, 39(1), 51-77.

Storey, V. A., \& Maughan, B. D. (2014). Beyond a definition: Designing and specifying Dissertation in Practice (DiP) models. The Carnegie Project on the Education Doctorate.

Stoskopf, A. (1999). An untold story of resistance: African-American educators and IQ testing in the 1920s and '30s. Rethinking Schools, 14(1). Retrieved from https://www.rethinkingschools.org/articles/an-untoldstory-of-resistance

Stout, J. (2010). Blessed are the organized: Grassroots democracy in America. Princeton, NJ: Princeton University Press.

Strauss, A., \& Corbin, J. M. (1990). Basics of qualitative research: Grounded theory procedures and techniques. Thousand Oaks, CA: Sage Publications, Inc.

Strauss, A., \& Glaser, B. (1967). The discovery of grounded theory: Strategies for qualitative research. Chicago, IL: Aldine Company.

Taysum, A. (2006). The distinctiveness of the EdD within the university tradition. Journal of Educational Administration and History, 38(3), 323334. https://doi.org/10.1080/00220620600984255

Theoharis, G. (2015). School leadership development requires LGBTQ content. Research and Support for Multicultural Education Course Requirements in Teacher Education in New York State, 42.

Thomas, G., \& James, D. (2006). Reinventing grounded theory: Some questions about theory, ground, and discovery. British Educational Research, 32(6), 767-795.
Tupling, C. L., \& Outhwaite, D. (2017). Developing an identity as an EdD leader: A reflexive narrative account. Management in Education, 31(4), 153-158. https://doi.org/10.1177/0892020617734819

Tural, E. (2017). Organizational transformations in community design centers: An analysis through Giddens' theory of structuration framework. Journal of Community Practice, 25(2), 253-282.

Winkle-Wagner, R. \& Locks, A.M. (2013). Diversity and inclusion on campus: Supporting racially and ethnically underrepresented students. New York: NY: Routledge.

Yang, G. (2016). Narrative agency in hashtag activism: The case of \#BlackLivesMatter. Media and Communication, 4(4), 13-17. https://doi.org/10.17645/mac.v4i4.692. 